\title{
PENGARUH MODEL PEMBELAJARAN TWO STAY TWO STRAY TERHADAP PENGUASAAN KOMPETENSI PENGETAHUAN IPA
}

\author{
Ni Putu Melinda Pramesti Tasya Dhevi \\ Universitas Pendidikan Ganesha, Singaraja, Indonesia \\ tasyadevinpmp@undilsha.ac.id \\ I Made Putra \\ Program Studii Teknologi Pendidikan, Universitas Pendidikan Ganesha \\ putraim@undiksha.ac.id \\ I Wayan Darsana \\ Program Studii Teknologi Pendidikan, Universitas Pendidikan Ganesha \\ iwydarsna@undiksha.ac.id
}

\begin{abstract}
Abstrak
Penelitian ini bertujuan untuk mengetahui pengaruh yang signifikan terhadap penguasaan kompetensi pengetahuan IPA antara siswa yang menggunakan model pembelajaran TSTS dan siswayangmenggunakan model pembelajaran konvensional pada siswa kelas V semester II di SD Negeri Gugus Mohammad Hatta. Jenis penelitian ini adalah penelitian eksperimen semu. Populasi penelitian ini adalah seluruh kelas V SD Negeri Gugus Mohammad HattaTahun Pelajaran 2018/2019 yang berjumlah 106 siswa. Sampel penelitian ini yaitu kelas V SD Negeri 3 Panjer yang berjumlah 44 siswa dan siswa kelas V SD Negeri 6 Panjer yang berjumlah 31 siswa. Metode dalam pengumpulan data dilakukan dengan metode tes yaitu dengan tes obyektif. Data yang diperoleh dianalisis dengan uji-t. Hasil penelitian ini menunjukkan perbedaan yang signifikan bahwa terdapat perbedaan penguasaan kompetensi pengetahuan IPA yang menggunakan model pembelajaran TSTS dan siswa yang menggunakan model pembelajaran konvensional dengan $t_{\text {hitung }}=10,704>t_{\text {tabel }}=2,000$ adanya perbedaan yang signifikan. Berdasarkan hasil analisis data model pembelajaran TSTS berpengaruh terhadap penguasaan kompetensi pengetahuan IPA. Hal ini dapat dilihat dari nilai rata-rata siswa yang menggunakan model pembelajaran TSTS yaitu 80,45 dan nilai rata-rata siswa yang menggunakan model pembelajaran konvensional yaitu 55,48. Perbaikan dilakukan dalam proses pembelajaran IPA dengan menggunakan modelpembelajaran TSTS terhadap penguasaan kompetensi pengetahuan IPA yang mampu mengatasi kendala-kendala dalam proses pembelajaran dikelas.
\end{abstract}

Kata Kunci: IPA, Penguasaan Kompetensi, TSTS

\begin{abstract}
The aim of this study was to investigate the significant effect on students' IPA competency between students taught using TSTS teaching strategy and students taught using conventional strategy in second semester of fifth-grade students in SD Negeri Gugus Mohammad Hatta. This study was quasi-experimental approach. The population of this study were 106 of fifth-grade students in SD NegeriGugus Mohammad Hatta in academic year 2018/2019. The sample of this study were 44 of fifth-grade students in SD Negeri 3 Panjer and 31 of fifth-grade students in SD Negeri 6 Panjer. The data collection procedure was done through multiple choice test. The obtained data were analyzed by using t-test. The result of the study showed that there was a significant effect on students' IPA competency between students taught using TSTS teaching strategy and students taught using conventional strategy, in which $t_{\text {observe }}$ was higher than $t_{\text {table }}(10.704>2.000)$. It also supported by the result of mean score, in which the mean score of experimental group was higher than control group $(80.45>55.48)$. Thus, the use of TSTS teaching strategy could help the students to solve the problems during the learning process, especially in IPA class.
\end{abstract}

Keywords: IPA, Competency, TSTS 


\section{Pendahuluan}

Kurikulum 2013 adalah kurikulum yang berlaku dalam Sistem Pendidikan Indonesia. Kurikulum ini merupakan kurikulum tetap diterapkan oleh pemerintah untuk menggantikan Kurikulum 2006 (yang sering disebut sebagai Kurikulum Tingkat Satuan Pendidikan) yang telah berlaku selama kurang lebih 6 tahun.Kurikulum 2013 masuk dalam masa percobaan pada tahun 2013 dengan menjadikan beberapa sekolah menjadi sekolah rintisan. Pada tahun ajaran 2013/2014, tepatnya sekitar pertengahan tahun 2013, Kurikulum 2013 diimplementasikan secara terbatas pada sekolah perintis, yakni pada kelas I dan VI untuk tingkat Sekolah Dasar.

Kurikulum 2013 memiliki empat aspek penilaian, yaitu aspek pengetahuan, aspek keterampilan, aspek sikap dan perilaku. Didalam kurikulum 2013, terutama di dalam materi pembelajaran terdapat materi yang dirampingkan dan materi yang ditambahkan. Materi yang dirampingkan terlihat ada di materi Bahasa Indonesia, IPS, PPKn. Sedangkan materi yang ditambahkan adalah materi Matematika.

Kurikulum 2013 yang berpusat pada guru menjadi pembelajaran berpusat pada peserta didik. Peserta didik harus memiliki pilihan-pilihan terhadap materi yang dipelajari untuk memiliki kompetensi yang sama. Pola pembelajaran satu arah (interaksi guru-peserta didik) menjadi pembelajaran interaktif (interaktif guru-peserta didik masyarakat lingkungan alam, sumber/media lainnya).

Pola pembelajaran terisolasi menjadi pembelajaran secara jejaring (peserta didik dapat menimba ilmu dari siapa saja dari siapa saja dan dari mana saja yang dapat dihubungi). Pola pembelajaran pasif menjadi pembelajaran aktif mencari (pembelajaran siswa aktif mencari semakin diperkuat dengan model pembelajaran pendekatan sains). Pola belajar sendiri menjadi belajar kelompok berbasis tim. Pola pembelajaran alat tunggal menjadi pembelajaran berbasis alat multimedia. Pola pembelajaran berbasis missal menjadi kebutuhan pelanggan (users) dengan memperkuat pengembangan potensis khusus yang dimiliki setiap peserta didik.Pola pembelajaran ilmu pengetahuan tunggal (monodiscipline) menjadi pembelajaran ilmu pengetahuan jamak (multidisciplines) dan pola pembelajaran pasif menjadi pembelajaran kritis.

Karakteristik Kurikulum 2013 dirancang dengan karakteristik sebagai berikut. Mengembangkan keseimbangan antara pengembangan sikap spiritual dan sosial, rasa ingin tahu, kreativitas, kerja sama dengan kemampuan intelektual dan psikomotorik. Sekolah merupakan bagian dari masyarakat yang memberikan pengalaman belajar terencana dimana peserta didik menerapkan apa yang dipelajari di sekolah ke masyarakat dan memanfaatkan masyarakat sebagai sumber belajar. Mengembangkan sikap, pengetahuan, dan keterampilan serta menerapkannya dalam berbagai situasi disekolah dan masyarakat. Memberi waktu yang cukup leluasa untuk mengembangkan berbagai sikap, pengetahuan, dan keterampilan. Kompetensi dinyatakan dalam bentuk kompetensi inti kelas yang dirinci lebih lanjut dalam kompetensi dasar mata pelajaran. Kompetensi inti kelas menjadi umur pengorganisasian (organizing elements) kompetensi dasar, dimana semua kompetensi dasar dan proses pembelajaran dikembangkan untuk mencapai kompetensi yang dinyatakan dalam kompetensi inti dan kompetensi dasar dikembangkan didasarkan pada prinsip akumulatif, saling memperkuat dan memperkaya antar mata pelajaran dan jenjang pendidikan (organisasi horizontal dan vertical).

Menurut Herawati (2015) Pendidikan adalah faktor penting dalam usaha mencerdaskan kehidupan bangsa.Oleh karena itu, proses-proses yang terjadi selama pendidikan berlangsung sebaiknya dikembangkan dan diarahkan untuk menghasilkan sumber daya manusia yang berkualitas. Guru sebagai pendidik mempunyai tujuan utama dalam kegiatan pembelajaran disekolah yaitu menciptakan suasana belajar yang menyenangkan, dapat menarik minat dan antusias siswa serta dapat memotifasi siswa untuk senantiasa belajar dengan baik dan semangat, dengan suasana belajar yang menyenangkan akan berdampak positif dalam pencapaian prestasi belajar yang optimal. Latar belakang pendidikan guru, diakui sangat mempegaruhi kompetensi seorang guru dalam mengajar anak didik.Kurangnya penguasaan terhadap berbagai jenis metode, menjadi kendala dalam memilih dan menentukan metode mengajar. Pendidikan merupakan suatu hal yang penting dalam menjadikan manusia yang berilmu, berbudaya, bertakwa serta mampu menghadapi tantangan dimasa yang akan datang. Pendidikan tersebut juga akan melahirkan peserta didik yang cerdas serta mempunyai kompetensi dan skill untuk dikembangankan ditengah-tengah masyarakat. Untuk mewujudkan hal ini tidak terlepas dari faktor penentu dalam keberhasilan peserta didik dalam pendidikan. Pendidikan dalam konteks persekolahan lebih banyak dilaksanakan melalui pembelajaran. Pembelajaran dapat diartikan sebagai suatu upaya mengkondisikan siswa untuk dapat belajar secara efektif. Kegiatan belajar efektif terlihat bahwa ada kegiatan memilih, menetapkan dan mengembangkan metode untuk mencapai hasil yang diinginkan dalam proses pembelajaran yang dilakukan oleh siswa dan guru. Pendidikan dalam persekolahan diharapakan siswa terlibat aktif dalam proses pembelajaran dikelas. Proses pembelajaran dikelas harus melibatkan siswa secara aktif dalam proses diskusi kelompok. Proses diskusi dikatakan akan lebih efektif apabila menggunakan media pembelajaran yang mendukung didalam proses pembelajaran. Media pembelajaran yang inovatif harus mampu mengajak siswa untuk berpikir secara ilmiah tentang pembelajaran yang disampaikan pada saat proses pembelajaran yaitu khususnya mata pelajaran IPA.

IPA (Ilmu Pengetahuan Alam) merupakan salah satu program pengajaran, di jenjang sekolah dasar IPA membahas menciptakan pembelajaran yang cenderung melibatkan siswa aktif, menemukan pengetahuan sendiri dikaitkan langsung dengan lingkungan dan pengalaman siswa, sehingga pembelajaran menjadi bermakna bagi 
siswa. Berdasarkan hasil observasi dan wawancara yang dilakukan pada hari Selasa, 13 November 2018 dengan guru mata pelajaran IPA dan siswa di SD Gugus Mohammad Hatta menunjukkan bahwa guru belum mampu mengaplikasikan berbagai model yang bervariatif. Pembelajaran yang demikian menyebabkan siswa kurang aktif mengikuti pembelajaran. Pembelajaran yang tidak menggunakan model pembelajaran menyebabkan siswa kurang dalam diskusi kelompok. Siswa yang aktif dalam pembelajaran hanyalah siswa yang pintar, sedangkan siswa yang memiliki kemampuan kurang hanya menjadi pendengar dan hanya menunggu perintah dari guru selama proses pembelajaran berlangsung. Hal ini menyebabkan aktivitas siswa dalam proses pembelajaran rendah. Interaksi dan kerjasama siswa dalam menyelesaikan suatu permasalahan di dalam kelompok umumnya masih kurang dalam artian sikap individu masih tinggi sebagian besar siswa yang jarang melakukan tukar informasi dengan teman kelompoknya, ketika diberikan tugas berkelompok dikelasnya dan tidak mau saling membantu dalam memecahkan masalah.

Menurut Jamaluddin (2019) Melalui pembelajaran IPA peserta didik dapat memiliki pemahaman tentang alam semesta dalam bentuk fakta, konsep, prinsip, prosedur dan teori yang dapat diterapkan dalam kehidupan sehari-hari. Pendidikan IPA telah berkembang di negara-negara maju dan telah terbukti dengan adanya penemuan-penemuan baru yang terkait dengan teknologi. Akan tetapi di Indonesia sendiri belum mampu mengembangkannya. Pendidikan IPA di Indonesia belum mencapai standar yang diinginkan. Padahal untuk memajukan IPTEK keterampilan berpikir dan pemahaman tentang sains peserta didik menjadi sangat penting untuk mampu berkompetisi dalam persaingan global dewasa ini dan dimasa yang akan datang. Menurut Muakhirin (2014) model pengajaran IPA yang diterapkan sejak awal hingga sekarang masih bersifat konvensional atau teacher centered, dimana sistem penyampaiannya lebih banyak didominasi oleh guru, serta proses komunikasinya satu arah. Guru yang memegang kendali memainkan peran aktif, sementara siswa duduk menerima secara pasif informasi pengetahuan dan keterampilan. Siswa-siswa cenderung diam dan kurang berani menyatakan gagasannya. Kreativitas dan kemandirian mengalami hambatan dan bahkan tidak berkembang. Di samping itu, pengalaman yang didapat anak dalam proses pembelajaran sangat terbatas sehingga mereka tidak dapat mengembangkan keterampilan proses yang dimiliki. Guru masih kurang mengoptimalkan penggunaan berbagai media yang dapat mendukung siswa untuk belajar lebih nyata. Penggunaan media pembelajaran yang masih kurang, ini terlihat dari guru masih menggunakan media seadanya yang ada di sekolah, sebenarnya setiap sekolah diberikan LCD proyektor untuk membantu guru mengajar dalam proses pembelajaran, tetapi sebaliknya karena dengan keterbatasan waktu dan kurang memahami menggunakan media tersebut maka guru merasa malas menggunakan media tersebut. Hal ini menyebabkan kemampuan belajar siswa menjadi rendah.

Berdasarkan kendala-kendala tersebut telah terjadi kesenjangan antara harapan dan kenyataan dalam pembelajaran khususnya dalam pengetahuan IPA, sebagian masih di bawah KKM dimana KKM dari pengetahuan IPA yang diharapkan dalam Kurikulum 2013 adalah 70,00. Dari 262 jumlah siswa kelas V yang berada di SD Gugus Mohammad Hatta, 11 siswa mendapat nilai (A), 15 siswa mendapat nilai (A-), 36 siswa mendapat nilai $(\mathrm{B}+), 40$ siswa mendapat nilai (B), 25 siswa mendapat nilai (B-), 15 siswa yang mendapat nilai $(\mathrm{C}+), 36$ siswa yang mendapat nilai (C), 38 siswa yang mendapat nilai (C-), 40 siswa yang mendapat nilai (D+), 42 siswa yang mendapat nilai (D). Dari 262 jumlah siswa kelas V sebanyak 125 Siswa sudah mencapai KKM, sedangkan $66 \%$ dari 262 siswa yang belum mencapai KKM. Hal ini mengindikasikan bahwa ketuntasan belajar pada muatan materi IPA di SD Gugus Mohammad Hatta tersebut belum terpenuhi dan perlu mendapat penanganan yang serius. Melihat kondisi seperti itu, perlu kiranya melakukan pengembangan dan peningkatan mutu dalam pembelajaran IPA, yakni pembelajaran yang mampu mengoptimalkan interaksi setiap elemen untuk menumbuh kembangkan kemampuan berpikir. Upaya mengembangkan kemampuan berpikir salah satunya dapat dilakukan dengan jalan membangun pemahaman pada diri siswa. Peranan guru sangat penting dalam proses pembelajaran yaitu guru memiliki kekuasaan penuh untuk mengatur dan menentukan proses pembelajaran. Diperlukan inovasi dari guru untuk mengemas suatu pembelajaran IPA. Model-model pembelajaran kooperatif suatu struktur tugas dan penghargaan yang berbeda diberikan dalam mengupayakan pembelajaran siswa. Salah satu model pembelajaran kooperatif, yaitu teknik belajar mengajar (Two Stay Two Stray) disingkat TSTS.

Model pembelajaran Two Stay Two Stray memberi kesempatan kepada kelompok untuk membagikan hasil dan informasi dengan kelompok lainnya. Berikut adalah caranya. Siswa bekerja sama dalam kelompok berempat seperti biasa. Setelah selesai, dua orang dari masing-masing bertamu kedua kelompok yang lain. Dua orang yang tinggal dalam kelompok bertugas membagikan hasil kerja dan informasi mereka ke tamu mereka. Tamu mohon diri dan kembali ke kelompok mereka sendiri dan melaporkan temuan mereka dari kelompok lain. Kelompok mencocokkan dan membahas hasil kerja mereka.

Teknik belajar mengajar Dua Tinggal Dua Tamu (Two Stay Two Stray). Struktur dua tinggal dua tamu memberi kesempatan kelompok untuk membagikan hasil dan informasi dengan kelompok lain. Model pembelajaran kooperatif dua tinggal dua tamu adalah dua orang siswa tinggal di kelompok dan dua orang siswa bertamu ke kelompok lain. Dua orang yang tinggal bertugas memberikan informasi kepada tamu tentang hasil kelompoknya, sedangkan yang bertamu bertugas mencari mencatat hasil diskusi kelompok yang dikunjunginya.

Adapun kelebihan model pembelajaran menurut Shoimin (2014) adalah sebagai berikut: 1) mudah dipecah menjadi berpasangan; 2) lebih banyak tugas yang bisa dilakukan; 3) guru mudah memonitoring; 4) dapat 
diterapkan pada semua kelas/tingkatan; 5) kecenderungan belajar siswa menjadi lebih bermakna; 6) lebih berorientasi pada keaktifan; 7) diharapkan siswa akan berani mengungkapkan pendapatnya; 8) menambah kekompakan dan rasa percaya diri siswa; 9) kemampuan berbicara siswa dapat ditingkatkan; 10) membantu meningkatkan minat dan prestasi belajar.

Berdasarkan hal tersebut model pembelajaran Two Stay Two Stray lebih menekankan pada keaktifan siswa dalam belajar sehingga materi yang diperoleh oleh siswa secara cepat dan nyata yang diberikan oleh masing-masing kelompok yang lainnya. Model ini juga memberikan lebih memotivasi siswa dalam belajar sehingga siswa tidak terfokus kepada guru saja.

Berdasarkan pemaparan di atas, diduga terdapat perbedaan kompetensi pengetahuan IPA siswa yang menggunakan pembelajaran model pembelajaran Two Stay Two Stray dengan siswa yang tidak menggunakan model pembelajaran Two Stay Two Stray. Oleh karena itu, diperlukan melakukan kajian tentang model pembelajaran yang paling efektif dalam upaya untuk meningkatkan penguasaan kompetensi pengetahuan IPA siswa, sehingga difokuskan penelitian yang berjudul. Pengaruh Model Pembelajaran Two Stay Two Stray Terhadap Kompetensi Pengetahuan IPA Kelas V Semester Genap di SD Gugus Mohammad Hatta Tahun Pelajaran 2018/2019.

\section{Metode}

Penelitian ini dilaksanakan di Gugus Mohammad Hatta pada semester genap tahun pelajaran 2018/2019. Penentuan waktunya disesuaikan dengan kalender pendidikan di Gugus Mohammad Hatta. Subjek penelitian ini adalah anak kelas V di Gugus Mohammad Hatta.

Jenis penelitian ini adalah penelitian eksperimen semu (quasi experiment) adalah "penelitian yang bertujuan untuk menguji keefektifan suatu teori/konsep/model dengan cara menerapkan (treatment) pada suatu kelompok subjek peneliti dengan menggunakan kelompok pembanding yang bisa disebut kelompok kontrol" (Agung, 2014).

Rancangan penelitian ini menggunakan penelitian quasi eksperimen dengan menggunakan desain penelitian Non Equivalent Posttest Only Control Group Design. Desain penelitian ini dimulai dengan terlebih dahulu menentukan kelompok yang akan diberikan perlakuan, kemudian kelompok tersebut diberikan perlakuan yang berbeda, setelah itu kedua kelompok sama-sama diberikan tes akhir untuk melihat apakah ada pengaruh dari perlakuan.Adapun gambaran dari bagan, desain penelitian sebagai berikut.

Tabel 1. Desain PenelitianNon Equivalen Posttest Only Control Group Design

\begin{tabular}{ccc}
\hline Kelompok & Perlakuan $(\mathbf{x})$ & Tes Akhir \\
\hline $\mathrm{E}$ & $\mathrm{X}_{1}$ & $\mathrm{O}_{1}$ \\
$\mathrm{~K}$ & $\mathrm{X}_{2}$ & $\mathrm{O}_{2}$ \\
\hline
\end{tabular}

Keterangan:

E : Kelompok Eksperimen

K : Kelompok Kontrol

$\mathrm{X}_{1}$ : kelompok yang mendapat perlakuan dengan model Two Stay Two Stray (eksperimen)

$\mathrm{X}_{2}$ : Dibelajarkan secara konvensional (kelompok kontrol)

$\mathrm{O}_{1}$ : tes akhir (Post-test) kelompok eksperimen

$\mathrm{O}_{2}$ : tes akhir (Post-test) kelompok kontrol.

Populasi penelitian ini adalah seluruh di SD Gugus Mohammad Hatta yang berjumlah 262 siswa. Penentuan sampel kelas dilakukan dengan teknik random sampling.Kelompok eksperimen diberikan model pembelajaranTwo Stay Two Straydan kelompok kontrol diberikan model pembelajaran konvensional.Desain Penelitian yang digunakan adalah non-equivalent post-test only kontrol group design.Pemilihan desain ini karena peneliti ingin mengetahui perbedaan penguasaan kompetensi antara kelompok eksperimen dan kelompok kontrol, dengan mengunakan metode post-test.

Data yang dianalisis dalam penelitian ini adalah penguasan kompetensi yang dikumpulkan melalui tes obyektif. Tes tersebut telah di uji coba lapangan, sehingga teruji validitas, reliabilitas, daya beda, dan tingkat kesukaran. Hasil tes uji lapangan tersebut selanjutnya diberikan kepada siswa kelas eksperimen dan kontrol sebagai post-test.

Analisis data yang digunakan dalam penelitian ini yaitu analisis statistik inferensialuntuk mencari uji normalitas dan uji homogenitas.Sedangkan teknik yang digunakan untuk menganalisis data guna menguji hipotesis penelitian adalah uji-t.Untuk bisa melakukan uji hipotesis, ada beberapa persyaratan yang harus dipenuhi dan perlu dibuktikan. Persyaratan yang dimaksud yaitu: (1) data yang dianalisis harus berdistribusi normal, (2) kedua data yang dianalisis harus bersifat homogen. Untuk dapat membuktikan dan mememenuhi 
persyaratan tersebut, maka dilakukanlah uji prasyarat analisis dengan melakukan uji normalitas, dan uji homogenitas.

Tabel 2. Data Jumlah Kelas SD Negeri Gugus Mohammad Hatta

\begin{tabular}{|c|c|c|c|}
\hline No & Nama Sekolah & Kelas & Jumlah Siswa \\
\hline 1 & SD 1 Panjer & $\mathrm{V}$ & 48 \\
\hline 2 & SD 2 Panjer & $\mathrm{V}$ & 48 \\
\hline 3 & SDN 3 Panjer & $\mathrm{V}$ & 44 \\
\hline \multirow{2}{*}{4} & \multirow{2}{*}{ SDN 4 Panjer } & VA & 30 \\
\hline & & VB & 30 \\
\hline \multirow{3}{*}{5} & \multirow{2}{*}{ SDN 6 Panjer } & VA & 31 \\
\hline & & VB & 31 \\
\hline & $\sum$ & & 262 \\
\hline
\end{tabular}

(Sumber: Administrasi Sekolah di Gugus Mohammad Hatta)

Jika dari keseluruhan populasi yang ada, kemudian hanya diambil sebagian menjadi wakil populasi tersebut, maka wakil populasi tersebut dinamakan sampel. Jadi sampel merupakan bagian dari populasi yang secara langsung dikenai penelitian. Sejalan dengan ini, Agung (2016:8) menyatakan bahwa "sampel adalah bagian dari jumlah dan karakteristik yang dimiliki oleh populasi tersebut”.

Teknik group random sampling adalah suatu cara pengambilan sampel secara acak, sampel diambil berdasarkan kelas bukan individu, setiap anggota populasi atau bagian dari populasi tersebut mempunyai kesempatan yang sama untuk dipilih sebagai sampel Koyan, (2012:30). Teknik group random sampling yang digunakan dalam menentukan kelas eksperimen dan kontrol dalam penelitian dengan cara undian.

Sebelum dilakukan penentuan sampel penelitian, dilakukan uji kesetaraan pada semua sekolah SD yang ada di Gugus Mohammad Hatta Kecamatan Denpasar Selatan (hasil uji kesetaraan dilampirkan). Data yang digunakan dalam uji kesetaraan adalah nilai ulangan akhir semester (UAS) ganjil mata pelajaran IPA kelas V.

Teknik group random sampling yang dirandom kelasnya, sehingga setiap kelas mendapatkan peluang yang sama untuk menjadi sampel penelitian. Penelitian sampel penelitian. Pemilihan sampel penelitian ini tidak dilakukan pengacakan individu melainkan hanya pengacakan kelas. Karena tidak bisa mengubah kelas yang tidak terbentuk sebelumnya. Kelas dipilih sebagaimana telah terbentuk tanpa campur tangan peneliti dan tidak dilakukannya pengacakan individu, kemungkinan pengaruh-pengaruh dari keadaan siswa mengetahui dirinya dilibatkan dalam eksperimen dapat dikurangi sehingga penelitian ini benar-benar menggambarkan pengaruh perlakuan yang diberikan.

Pengambilan sampel dilakukan dengan dua kali pengundian. Pengundian tahap pertama untuk memilih dua kelas yang dijadikan sampel penelitian dengan cara menulis semua nama kelas V di Gugus Mohammad Hatta pada masing-masing kertas yang jumlahnya 7 kelas kemudian kertas digulung. Masukkan gulungan kertas ke dalam kotak dan kocok. Ambil satu gulungan kertas, lalu ambil satu gulungan kertas lain, tanpa masukkan kembali gulungan kertas pertama. Berdasarkan pengundian yang dilakukan kelas V SD Negeri 3 Panjer berjumlah 44 siswa muncul pertama dan kelas VA SD Negeri 6 Panjer yang berjumlah 32 siswa muncul kedua. Kedua kelas yang terpilih menjadi sampel kemudian diundi kembali untuk menentukan kelas eksperimen dan kelas kontrol. Berdasarkan pengundian yang dilakukan, kelas V SD Negeri 3 Panjer sebagai kelas eksperimen dan kelas VA SD Negeri 6 Panjer sebagai kelas kontrol. Pada kelas eksperimen diberikan perlakuan berupa model pembelajaran Two Stay Two Stray dan pada kelas kontrol diberikan perlakuan berupa pembelajaran konvensional.

Berdasarkan pengundian yang telah dilakukan bahwa kelas V SDN Gugus Mohammad Hatta, SDN 3 Panjer berjumlah 44 siswa dan SDN 6 Panjer berjumlah 31 siswa sebagai sampel.

Tabel 3. Sampel Penelitian dengan Teknik Group Random Sampling

\begin{tabular}{|c|c|c|}
\hline Nama Sekolah & Kelas & Jumlah Siswa \\
\hline SDN 3 Panjer & $\mathrm{V}$ & 44 \\
\hline SDN 6 Panjer & VA & 31 \\
\hline \multicolumn{2}{|c|}{ Total } & 75 \\
\hline
\end{tabular}




\section{Hasil dan Pembahasan}

Responden yang digunakan dalam penelitian ini sebanyak 75 anak, 44 anak kelompok eksperimen dan 31 anak kelompok kontrol. Kelompok eksperimen diterapkan pada model Two Stay Two Straydan kelompok kontrol diterapkan model pembelajaran konvensional.Sebelum melakukan uji hipotesis maka harus dilakukan beberapa uji prasyarat terhadap sebaran data yang meliputi uji normalitas dan uji homogenitas terhadap kemampuan penguasaan kompetensi IPA.

Uji normalitas sebaran data dilakukan untuk mengetahui apakah data yang diperoleh berdistribusi normal atau tidak. Jika berdistribusi normal maka uji hipotesis dapat dilakukan.Uji normalitas dalam penelitian ini menggunakan uji Chi Square. Tabel data kelompok eksperimen dan kontrol pada Tabel 2.

Tabel 4. Rangkuman Hasil Uji Normalitas

\begin{tabular}{|c|c|c|c|c|}
\hline No & $\begin{array}{c}\text { Kelompok Data Kompetensi Pengetahuan } \\
\text { IPA }\end{array}$ & $\chi^{2}$ hitung & $\chi_{\text {tabel }}^{2}$ & Status \\
\hline 1 & Post-test Eksperimen & 3,83 & 11,07 & Normal \\
\hline 2 & Post-test Kontrol & 1,07 & 11,07 & Normal \\
\hline
\end{tabular}

Berdasarkan pada Tabel diatas dengan perhitungan sebaran data kelompok eksperimen menunjukkan $\mathrm{dk}=6-1=5$ pada tabel $\chi 2$ untuk taraf signitifkan $5 \%=11,07$. Dengan demikian, harga $\chi 2_{\text {hitung }}=3,83<\chi 2_{\text {tabel }}=$ 11,07, sehingga $\mathrm{H}_{0}$ diterima sehingga dapat disimpulkan bahwa sampel berasal dari populasi distribusi normal. Pada kelompok kontrol $\mathrm{dk}=6-1=5$ pada tabel $\chi^{2}$ untuk taraf signifikan $5 \%=11,07$. Jadi, data post-test kelompok kontrol berdistribusi normal.

Selanjutnya uji homogenitas dilakukan terhadap varians pasangan antar kelompok eksperimen dan kontrol. Uji homogenitas varians antar kelompok bertujuan untuk memeriksa kesamaan varians antar kelompok perlakuan. Dalam penelitian ini, uji homogenitas dilakukan terhadap varians pasangan antar kelompok eksperimen dan kontrol. Uji yang digunakan adalah uji-F dengan kriteria data homogen jika $F_{\text {hitung }}<F_{\text {tabel. }}$. Rekapitulasi hasil uji homogenitas antar kelompok eksperimen dan kontrol disajikan pada tabel 3 di bawah ini.

Tabel 5. Hasil Uji Homogenitas antar Kelompok Eksperimendan Kontrol

\begin{tabular}{lccc}
\hline \multicolumn{1}{c}{ Data } & $\mathbf{F}_{\text {hitung }}$ & $\mathbf{F}_{\text {tabel }}$ & Kesimpulan \\
\hline $\begin{array}{l}\text { Post-test Kelompok Eksperimen dan } \\
\text { Kelompok Kontrol }\end{array}$ & 1,15 & 1,93 & Homogen \\
\hline
\end{tabular}

Berdasarkan Tabel 5, diketahui $\mathrm{F}_{\text {hitung }}$ hasil kelompok eksperimen dan kontrol adalah 1,15 sedangkan $\mathrm{F}_{\text {tabel }}$ pada $\mathrm{db}_{\text {pembilang }}=43, \mathrm{db}_{\text {penyebut }}=30$, dan taraf signifikansi $5 \%$ adalah 1,93 . Hal ini berarti, varians data kompetensi pengetahuan IPA kelompok eksperimen dan kontrol adalah homogen.

Berdasarkan uji prasyarat analisis data, diperoleh bahwa data hasil post-test kelompok eksperimen dan kontrol adalah normal dan homogen.Setelah diperoleh hasil dari uji prasyarat analisis data, dilanjutkan dengan pengujian hipotesis penelitian $\left(\mathrm{H}_{1}\right)$ dan hipotesis nol $\left(\mathrm{H}_{0}\right)$.Kriteria pengujian adalah tolak $\mathrm{H}_{0}$ jika $t_{\text {hitung }}>t_{\text {tabel }}$, dimana $\mathrm{t}_{\text {tabel }}$ diperoleh dari tabel distribusi $\mathrm{T}$ pada taraf signifikansi $5 \%$ dengan derajat kebebasan $\mathrm{db}=\mathrm{n}_{1}+\mathrm{n}_{2}-$ 2. Rangkuman hasil analisis uji-t ditampilkan pada tabel 4 berikut.

Tabel 6. Hasil Uji-t

\begin{tabular}{lccccc}
\hline \multicolumn{1}{c}{ Kelompok } & $\mathbf{N}$ & $\mathbf{D b}$ & Mean & $\mathbf{t}_{\text {hitung }}$ & $\mathbf{t}_{\text {tabel }}$ \\
\hline Eksperimen & 44 & 73 & 80,45 & 10,704 & 2,000 \\
Kontrol & 31 & & 55,48 & & \\
\hline
\end{tabular}

Berdasarkan Tabel 6 , diperoleh $\mathrm{t}_{\text {hitung }}=10,704$. Adapun nilai $\mathrm{t}_{\text {tabel }}$ dengan taraf signifikansi $5 \%$ dan derajat kebebasan $\mathrm{dk}=44+31-2=73$ adalah 2,000.Jadi dapat disimpulkan bahwa terdapat pengaruh yang signifikan penguasaan kompetensi pengetahuan IPA, antara anak yang mendapatkan model pembelajaran Two Stay Two Staydengan kelompok kontrol yang mendapat model pembelajaran konvensional terhadap penguasaan kompetensi pengetahuan IPA siswa kelas V Tahun Ajaran 2018/2019. Dengan adanya pengaruh yang signifikan penguasaan kompetensi pengetahuan IPA kelompok eksperimen dan kelompok kontrol, hal ini berarti bahwa 
model pembelajaranTwo Stay Two Stray berpengaruh terhadap penguasaan kompetensi pengetahuan IPA siswa kelas V SD gugus Mohammad Hatta Tahun Ajaran 2018/2019.

Berdasarkan hasil penelitian yang telah dilakukan bahwa terdapat temuan yang berbeda antara model pembelajaran Two Stay Two Stray dengan model pembelajaran konvensional yang dilihat berdasarkan hasil post test. Dari hasil post test menunjukkan bahwa siswa yang dibelajarkan dengan model pembelajaran Two Stay Two Stray mendapatkan nilai rata-rata adalah 80,45 sedangkan nilai rata-rata siswa yang dibelajarkan dengan model pembelajaran konvensional adalah 55,48. Ini menunjukkan bahwa temuan dalam penelitian tersebut menunjukkan model pembelajaran Two Stay Two Stray lebih baik daripada model pembelajaran konvensional.

Hasil analisis data menunjukkan bahwa terdapat perbedaan model Two Stay Two Stray terhadap kompetensi pengetahuan IPA dengan siswa yang mengikuti model pembelajaran konvensional. Tinjauan ini didasarkan pada hasil uji-t dan rata-rata nilai kompetensi pengetahuan siswa. Analisis data menggunakan uji-t, diketahui $\mathrm{t}_{\text {hitung }}=10,704$ dan $\mathrm{t}_{\text {tab }}$ pada taraf signifikansi $5 \%=2,000$. Hasil perhitungan tersebut menunjukkan bahwa $t_{\text {hitung }}>t_{\text {tabel }}$. Hal ini berarti, terdapat perbedaan kompetensi pengetahuan IPA siswa yang signifikan antara kelompok siswa yang dibelajarkan menggunakan model pembelajaran Two Stay Two Stray dengan kelompok siswa yang dibelajarkan menggunakan model pembelajaran konvensional.

Model pembelajaran Two Stay Two Stray adalah model pembelajaran kooperatif yang menekankan suatu struktur tugas dan penghargaan yang berbeda diberikan dalam mengupayakan pembelajaran siswa dengan teknik belajar mengajar dua tinggal dua tamu dalam mencari materi pembelajaran.Teknik belajar mengajar Two Stay Two Stray. Struktur dua tinggal dua tamu memberi kesempatan kelompok untuk membagikan hasil dan informasi dengan kelompok lain. Model pembelajaran kooperatif dua tinggal dua tamu adalah dua orang siswa tinggal di kelompok dan dua orang siswa bertamu ke kelompok lain. Dua orang yang tinggal bertugas memberikan informasi kepada tamu tentang hasil kelompoknya, sedangkan yang bertamu bertugas mencatat hasil diskusi kelompok yang dikunjunginya. Berdasarkan pemaparan para ahli diatas dapat disimpulkan bahwa model Two Stay Two Stray adalah model pembelajaran yang mengajarkan siswa untuk belajar bekerja sama dengan teman kelompok maupun teman yang lain, untuk lebih meningkatkan pikiran kreatif siswa untuk mencari informasi yang baru dan siswa menjadi lebih aktif berbicara dan bertanya dalam proses pembelajaran.

Penelitian ini diperkuat oleh Rediarta (2014) menyimpulkan bahwa model pembelajaran Two Stay Two Stray berpengaruh yang terhadap hasil belajar IPA siswa kelas V di SD Gugus 13 Kecamatan Buleleng Tahun Pelajaran 2014/2015.

\section{Simpulan}

Berdasarkan analisis data kompetensi pengetahuan IPA pada kelompok eksperimen yang dibelajarkan dengan model Two Stay Two Stray diperoleh rata-rata eksperimen, $\bar{X}=80,45$ kompetensi pengetahuan IPA tersebut kemudian dikonversikan pada PAP skala lima, sehingga dapat diketahui kompetensi pengetahuan IPA kelompok eksperimen berada pada kategori Sangat tinggi.

Berdasarkan analisis data kompetensi pengetahuan IPA pada kelompok kontrol yang dibelajarkan melalui pembelajaran konvensional diperoleh skor rata-rata $\bar{X}=55,48$. Rata-rata kompetensi pengetahuan IPA tersebut kemudian dikonversikan pada tabel PAP skala lima, sehingga dapat diketahui kompetensi pengetahuan IPA kelompok kontrol pada kategori Sedang.

Terdapat perbedaan yang signifikan kompetensi pengetahuan IPA antara kelompok yang dibelajarkan melalui model pembelajaran Two Stay Two Stray dengan yang dibelajarkan melalui Pembelajaran Konvensional kelas V SD Gugus Mohammad Hatta Tahun Ajaran 2018/2019. Hal ini terbukti dari Hasil analisis uji-t diperoleh $\mathrm{t}_{\text {hitung }}=10,704$. Harga tersebut kemudian dibandingkan dengan harga $\mathrm{t}_{\text {tabel }}$ dengan $\mathrm{dk}=73$ dan taraf signifikansi $5 \%$ sehingga diperoleh $t_{\text {tabel }}=2,000$ karena $t_{\text {hitung }}=10,704>t_{\text {tabel }}=2,000$ maka $H_{o}$ diterima. Rata-rata kompetensi pengetahuan IPA kelompok eksperimen $\bar{X}_{1}=80,45>\bar{X}_{2}=55,48$ rata-rata kompetensi pengetahuan IPA kelompok kontrol, dengan demikian dapat disimpulkan bahwa model pembelajaran Two Stay Two Stray berpengaruh terhadap kompetensi pengetahuan IPA kelas V SD Gugus Mohammad Hatta Tahun Ajaran 2018/2019.

Saran yang dapat diberikan yaitu: 1) Sebagai wahana membelajarkan diri siswa untuk berbagi antar siswa yang satu dengan yang lain dan menyadarkan siswa bahwa belajar merupakan proses bukan berorientasi pada nilai saja. 2) Penelitian ini akan menambah wawasan pengetahuan dan informasi yang berguna mengenai model pembelajaran yang inovatif, khususnya tentang model pembelajaran Two Stay Two Stray untuk mampu meningkatkan minat dan prestasi belajar serta menambah kekompakkan dan rasa percaya diri siswa, dan diharapkan siswa akan berani mengungkapkan pendapatnya. 3) Penelitian ini sangat bermanfaat bagi sekolah dalam memperbaiki proses belajar mengajar pada pelajaran IPA dan memberikan masukan alternatif dalam proses pembelajaran yang inovatif untuk meningkatkan kemampuan guru dalam mengajar penguasaan 
kompetensi pengetahuan IPA. 4) Penelitian ini akan dijadikan sebagai bahan pertimbangan dan masukan bagi peneliti selanjutnya yang memerlukan tambahan dasar teori, baik untuk pengembangkan pembelajaran maupun penyelesaian tugas akhir.

\section{Daftar Pustaka}

Agung, A.A Gede. 2014. Metodotologi Penelitian Pendidikan. Singaraja: Universitas Pendidikan Ganesha. Aunurrahman. 2014. Belajar dan Pembelajaran. Bandung : Alfabeta.

Desmita. 2017. Psikologi Perkembangan Peserta Didik. Bandung: PT Remaja Rosdakarya.

Djaali. 2012. Psikologi Pendidikan. Jakarta: PT Bumi Aksara.

Herawati. 2015. Penerapan Model Pembelajaran Two Stay Two Stray untuk Meningkatkan Prestasi Belajar Siswa pada Materi Keliling dan Luas Lingkaran di Kelas VI SD Negeri 53 Banda Aceh. Jurnal Peluang, Volume 3, Nomor 2, Hal. 95-105. Tersedia Pada: http://jurnal.unsyiah.ac.id/peluang/article/view/5720.

Husna, dkk. 2013.’Peningkatan Kemampuan Pemecahan Masalah dan Komunikasi Matematis Siswa Sekolah Menengah Pertama Melalui Model Pembelajaran Kooperatif Tipe Think-Pair-Share (Tps)",Volume 1, Nomor 2 (hlm.83). http://www.jurnal.unsyiah.ac.id/peluang/article/view/1061

Hutagalung, Hj. Inge. 2007. Pengembangan Kepribadian. Jakarta: PT Indeks.

Jamaluddin, A. Wahab Jufri, Agus Ramdhani, Afriana Azizah. 2019. Profil Literasi Sains dan Keterampilan Berpikir Kritis Pendidik IPA SMP. Jurnal Penelitian Pendidikan IPA (JPPIPA) Vol. 15 No. 1 Hal. 120-130. Tersedia Pada: http://jppipa.unram.ac.id/index.php/jppipa/index. (diakses pada 04 Oktober 2013).

Kosasih, E.2014.Strategi Belajar dan Pembelajaran.Bandung: Yrama Widya.

Koyan, I Wayan. 2012. Statistik Pendidikan Teknik Analisis Data Kuantitatif. Singaraja: Universitas Pendidikan Ganesha.

Muakhirin, Binti. 2014. Peningkatan Hasil Belajar IPA melalui Pendekatan Pembelajaran Inkuiri pada Siswa SD. Jurnal Ilmiah Guru "COPE", No. 01 Hal. 51-57. Tersedia Pada: https://journal.uny.ac.id/index.php/cope/article/view/2933. (diakses pada 04 Oktober 2013).

Miraningsih, Wahyu. 2013. Hubungan antara Interaksi Sosial dan Konsep Diri dengan Perilaku Reproduksi Sehat Pada Siwa Kelaas XI di Madrasah Aliyah Negeri (MAN) Purwerejo. Semarang: Universitas Negeri Semarang. Tersedia pada https://lib.unnes.ac.id/17318/ (diakses pada 04 Oktober 2013).

Permendikbud. 2014. Salinan Lamiran Peraturan Menteri Pendidikan Dan Kebudayaan Republik Indonesia Nomor 103 Tahun 2014 Pembelajaran Pada Pendidikan Dasar Dan Pendidikan Menengah.

Rusman, 2014. Model-Model Pembelajaran Edisi Kedua. Cetakan kelima. Jakarta: Rajawali Pers.

Sanjaya, Wayan. 2017. Korelasi Antara Berfikir Kreatif Dengan Kemampuan Pemecahan Masalah Kompetensi Inti Pengetahuan IPS Kelas V SDN 10 Sanur Denpasar Selatan Tahun Pelajaran 2016/2017. Singaraja: Universitas Pendidikan Ganesha (Tidak diterbitkan)

Setyosari, Punaji. 2015. Metode Penelitian Pendidikan dan Pengembangan Edisi Keempat. Jakarta: Kencana Prenada Media Grup.

Siregar, Syofian. 2015. Statistik parametrik untuk penelitian kuantitatif. Jakarta: Bumi Aksara.

Sugiyono. 2013. Metode Penelitia Pendidikan Pendekatan Kuantitatif, Kualitatif dan R\&D. Bandung: Alfabeta. Sugiyono. 2015. Metode Penelitian Pendidikan. Bandung: Alfabeta.

Suharsimi, Arikuno.2015. Evaluasi Pendidikan. Jakarta:PT. Bumi Aksara

Supardi, U.S. 2013. Aplikasi Statistika dalam Penelitian Konsep Statistika yang Lebih Komprehensif. Jakarta: Change Publication.

Susanto, Ahmad. 2013. Teori Belajar \& Pembelajaran di Sekolah Dasar. Jakarta: Kencana.

Syah,Muhibbin. 2015. Psikologi Belajar. Jakarta : PT Raja Grafindo Persada.

Thalib, Syamsul Bachri. 2010. Psikologi Pendidikan Berbasis Analisi Empiris Aplikatif. Jakarta: Kencana.

Wena . 2014. Strategi Pembelajaran Inovatif Kontemporer, Cetakan Kesembilan. Jakarta: PT. Bumi Aksara. 